\title{
STUDY OF THE RENAL RESPONSE TO RAMIPRIL AND VALSARTAN IN RATS WITH LIVER CIRRHOSIS AND ASCITES
}

\author{
By \\ Karawan M.Abdel Rahman
}

\author{
From \\ Department of clinical pharmacology.
}

Faculty of Medicine. Mansoura University

\begin{abstract}
This study was designed to examine the effects of combined administration of the angiotensin receptor blocker (AT1RB), valsartan \& the angiotensin converting enzyme inhibitor (ACEI), ramipril on renal function in rats with liver cirrhosis. This animal model was induced by giving gradually increased intra-gastric doses of carbon tetrachloride $(\mathrm{CCl} 4)$.
\end{abstract}

Thirty male albino rats weighing 150-200 grams were used through this study. Rats were divided as the following:

Group (I) : formed of 6 non-cirrhotic control rats.

Group (II) : comprised 6 cirrhotic ascitic control rats.

Group (III) : Cirrhotic ascitic rats treated with ramipril in a dose of $2.5 \mathrm{mg} / \mathrm{kg} /$ day for 2 weeks.

Group (IV) : Cirrhotic ascitic rats treated with valsartan in a dose of $20 \mathrm{mg} / \mathrm{kg} /$ day for 2 weeks.

Group (V) : Cirrhotic ascitic rats treated with ramipril \& valsartan combination for 2 weeks.

Daily urine volume \& body weight were assessed to follow up the development \& progress of ascites. Urinary \& plasma sodium \& potassium were measured. In addition plasma renin activity (PRA) \& serum creatinine were estimated. In cirrhotic ascitic rats combination therapy with ramipril \& valsartan was more efficacious than either monotherapy in improving kidney function \& salt \& water retention. Ramipril is as equally effective as valsartan at ameliorating the decline in renal function \& salt 
\& water retention.

These results indicate that in rats with liver cirrhosis \& ascites, the reno protective effect afforded by combined RAS (renin- angiotensin system) blockade in this model adds further support to the involvement of a tissue based RAS. Although the present study reveals elevation in PRA either in association with monotherapy or combined therapy, RAS blockade improved renal function which indicating that a local RAS confers renoprotective effect. The enhancing effects of ramipril \& valsartan combination on renal electrolyte \& volume excretion may reduce the need for diuretics \& thus attenuates the risk of their induced electrolyte disturbances.

\section{INTRODUCTION}

In liver cirrhosis \& ascites, the renin angiotensin system is usually activated. Such a correlation supports the hypothesis that activation of the RAS plays role in the pathogenesis of ascites in liver cirrhosis (1). PRA is increased in hepatic cirrhosis \& is correlated with hepatic venous pressure gradient (2). Angiotensin II(Ang-II) is an important mediator of portal hypertension (3). Therefore, blockade of
RAS by ACEI/Ang II receptor antagonists should be beneficial for improvement of ascites, fluid \& salt excretion(4). Consequently, intensive research has focused over the years on developing drugs, such as ACEI, renin inhibitors \& Angll receptor antagonists that interfere with RAS at different levels (5).

The antihypertensive effect of ACEI has been mainly attributed to diminished formation of both plasma \& tissue Ang II \& due to accumulation of endogenous vasodilator kinins (6), as ACE catalyzes both the conversion of Angl to Ang II \& the degradation of bradykinins \& related kinins (7).

Although the administration of ACEls results in a fall in plasma Angll levels the efficacy of ACEI is probably limited by their inability to completely block ACE activity \& the generation of Ang II through other enzymatic pathways $(8,9)$. Longterm ACEI use associated with a return in circulating Ang II following a reactive rise in plasma renin \& Ang I due to interruption of Ang II feedback on renin release $(10)$. On the other hand angiotensin receptor blockers do not affect production of bradykinin \& should theoretically block the action of Ang II

Vol. 36, No. 3 \& 4 July., \& Oct, 2005 
chronically at the receptor level. Angiotensin receptors exist in two main forms, angiotensin receptors type -I (AT1) \& type-2 (AT2) receptors. The main target for angiotensin receptor blocker is the AT1 receptors, which mediate Angll-induced vaso constriction \& electrolyte homeostasis.(11)

Ramipril was selected among several analogs because of its unique physicochemical properties. It is a non-sulfhydryl ACE inhibitor, \& after oral absorption it is transformed in the liver into its active metabolite ramiprilate, which is at least 23 times more lipophilic than enalaprilate \& 47 times than for captopril.

Furthermore, the in vitro affinity of ramiprilate for the enzyme is higher than for enalaprilate \& captopril by several times. The ramiprilate-ACE complex is therefore very stable \& dissociates 6 times more slowly than the enalaprilate ACE complex \& 22 times more slowly than the captopril ACE complex. In addition ramipril possesses a favorable pharmacokinetic profile as a consequence of its physicochemical properties; its higher potency allows the use of very low dose \& the slow dissociation of the
ramipril-ACE complex explains the long duration of its action permitting a once-daily treatment(12).

Valsartan is a highly selective, orally available angiotensin receptor (AT1), antagonist. Experimental studies have confirmed the abolition or attenuation of Ang II related effects, such as vasoconstriction, cell growth promotion \& aldosterone release. In humans valsartan is rapidly absorbed with maximal plasma concentration occurring 1-2 hours after oral administration (13). Valsartan does not need to be metabolized to be effective. There is only one inactive metabolite. Since any AT receptor blockersinduced rise in Ang II should be attenuated by parallel ACE1 administration. The present study aimed to determine if a combination of ramipril \& valsartan confer greater benefit than single therapy alone in liver cirrhosis with ascites in rats.

\section{MATERIAL \& METHODS}

Drugs-used :

- Tritace tablets (each tab. contains $2.5 \mathrm{mg}$ ramipril) produced by Hoechst Co.

- Diovan tab. (valsartan, 160mg (tab.) supplied by Novartis Co.

- Carbon-tetra chloride $\left(\mathrm{CCl}_{4}\right)$ pro-

MANSOURA MEDICAL JOURNAL 
duced by adwic Co.; each $\mathrm{ml}$ contains 1 gram $\mathrm{CCl}_{4}$.

- Phenobarbitone powder: Alexandria Co.

\section{The experimental protocol:}

Thirty male albino rats weighing between 150-200grams. The animals were housed in a controlled environment. The animals were allowed free access to food \& water.

Liver cirrhosis was induced by weekly intra gastric administration of $\mathrm{CCl}_{4}$ (starting with 40ul/week \& increasing progressively up to 300 $400 u L / w e e k$, along with Phenobarbital in the drinking water $(0.35 \mathrm{gram} / \mathrm{L})$ accelerate induction of hepatic cirrhosis as previously described (14). The onset of ascites was detected by rapid weight gain associated with bulging of the flanks. When ascites developed, rats were given lower doses of $\mathrm{CCl}_{4}$ (80ul/ week) for 2 weeks \& then discontinued. This method was choosen to avoid spontaneous disappearance of ascites that may occur if $\mathrm{CCl} 4$ is stopped immediately after appearance of ascites (15). Liver cirrhosis started to appear 5-6 weeks after $\mathrm{CCl}_{4}$ administration. Sodium retention was detected about one week after the evidence of cirrhosis. $(16,17)$.
After occurrence of ascites, animals were housed individually in metabolic cages. Measurement of water, food intake, body weight \& urine volume were recorded daily. Urine specimens were collected daily \& frozen at $-70^{\circ} \mathrm{C}$ for later analysis. At the end of the experiment the rats were killed by decapitation. The diagnosis of cirrhosis was confirmed by visual examination at laparotomy. Blood samples were collected under ice in tubes containing EDTA \& the separated plasma was stored at $-70^{\circ} \mathrm{C}$ until the assessment of the following parameters:

- PRA by radioimmunoassay (18).

- Plasma \& urine sodium \& potassium by ion selective electrode electrolyte analyzer (avL988-Switzerland) (19).

- Serum \& urine creatinine by using the modified Jaffe method with (20) deproteinization utilizing Boehringer-Mannheim kits.

\section{Animal grouping :}

Thirty male albino rats were used in this study. The animals were randomly ciivided into 5 equal groups:

Group (I) : Non-cirrhotic control animals, treated with $0.5 \mathrm{ml} \mathrm{sa-}$ line intragastrically for 2 weeks . 
Group (II) : Cirrhotic ascitic control rats treated with $0.5 \mathrm{ml} \mathrm{sa}$ line for 2 weeks intragastrically.

Group (III) : Cirrhotic ascitic control rats treated with ramipril $2.5 \mathrm{mg} / \mathrm{kg} /$ day (21), intragastrically for 2 weeks.

Group (IV) : Cirrhotic ascitic control rats treated with valsartan (22), $20 \mathrm{mg} / \mathrm{kg} /$ day intragastrically for 2 weeks.

Group (V) : Cirrhotic ascitic control rats treated with combination of ramipril \& valsartan in same previous route, doses for 2 weeks.

\section{STATISTICAL ANALYSIS}

The result were carried out according to Pipkin (23), using the student " $\mathrm{t}$ " test. $\mathrm{P}$ values $<0.05$ were considered to be significant.

All values are expressed as mean \pm standard error of the mean (SEM).

\section{RESULTS}

The diagnosis of cirrhosis was confirmed by visual examination at laporatomy. At the time of study all the cirrhotic animals showed, marked ascites. Experimental induction of cirrhosis produced a significant increase in body weight as compared to noncirrhotic animals as illustrated in table (1). Cirrhotic untreated rats developed marked sodium \& water retention associated with increased urinary potassium excretion \& serum creatinine, but without changes in plasma potassium level as illustrated in table (1\&2).

Administration of ramipril to cirrhotic rats with ascites induced significant decrease in body weight \& urinary potassium excretion \& serum creatinine levels, but it produced a significant increased in plasma potassium, urine volume \& urinary sodium excretion as compared to cirrhotic non-treated rats (tab.1\&2).

Administration of valsartan in a dose of $20 \mathrm{mg} / \mathrm{kg} /$ day for 2 weeks to cirrhotic rats with ascites produced similar changes as previously mentioned with ramipril treatment.

Coadministration of ramipril and valsartan to cirrhotic rats with ascites produced additive decrease in body weight, urinary potassium excretion serum creatinine \& plasma sodium levels as compared to single drug administration. In contrast administration of the two drugs simultaneously developed a significant increase in urinary volume output, PRA \& urinary sodium excretion (table $1 \&$ 2).

MANSOURA MEDICAL JOURNAL 
Table (1): Effect of intragastric administration of ramipril and valsartan on body weight, urine volume, urinary sodium and potassium excretion in cirrhotic ascitic rats (Mean $\pm \mathrm{SE}$ ).

\begin{tabular}{|c|c|c|c|c|}
\hline $\begin{array}{c}\text { Animal group } \\
\qquad N=6\end{array}$ & $\begin{array}{c}\text { Bodyweight } \\
\text { (gm) }\end{array}$ & $\begin{array}{l}\text { Urinary } \\
\text { sodium } \\
(\mathrm{m} \mathrm{mol} / \mathrm{L})\end{array}$ & $\begin{array}{l}\text { Urinary } \\
\text { potassium } \\
(\mathrm{m} \mathrm{mol} / \mathrm{L}) \\
\end{array}$ & $\begin{array}{l}\text { Urine } \\
\text { volume } \\
(\mathrm{ml} / \mathrm{d})\end{array}$ \\
\hline Non-cirrhotic control & $240 \pm 5.1$ & $220 \pm 6.3$ & $145 \pm 4.6$ & $8.8 \pm 0.3$ \\
\hline Cirrhotic ascitic control & $\begin{array}{l}320=10.5 \\
P 1<0.001\end{array}$ & $\begin{array}{l}191 \pm 4.5 \\
\mathrm{P} 1<0.05\end{array}$ & $\begin{array}{l}178 \pm 1.8 \\
\mathrm{Pl}<0.05\end{array}$ & $\begin{array}{l}4.5 \pm 0.2 \\
\mathrm{PI}<0.05\end{array}$ \\
\hline $\begin{array}{l}\text { Cirrhotic rats treated with } \\
\text { ramipril }(2.5 \mathrm{mg} / \mathrm{kg} / \mathrm{day}) \text { for } 2 \\
\text { week }\end{array}$ & $\begin{array}{l}280 \pm 9.1 \\
P 2<0.05\end{array}$ & $\begin{array}{l}210 \pm 5.9 \\
P 2<0.05\end{array}$ & $\begin{array}{l}155 \pm 3.3 \\
P 2<0.05\end{array}$ & $\begin{array}{l}5.9 \pm 0.3 \\
P 2<0.05\end{array}$ \\
\hline $\begin{array}{l}\text { Cirrhotic rats treated with } \\
\text { valsartan }(20 \mathrm{mg} / \mathrm{kg} / \mathrm{day}) \text { for } 2 \\
\text { week }\end{array}$ & $\begin{array}{l}283 \pm 8.4 \\
P 3<0.05\end{array}$ & $\begin{array}{l}213 \pm 4.8 \\
P 3<0.05\end{array}$ & $\begin{array}{l}156 \pm 4.2 \\
P 3<0.05\end{array}$ & $\begin{array}{l}6.1 \pm 0.4 \\
P 3<0.05\end{array}$ \\
\hline $\begin{array}{l}\text { Cirrhotic rats treated with } \\
\text { combined ramipril \& valsartan } \\
\text { in previous doses for } 2 \text { week } \\
(2.5 \mathrm{mg} / \mathrm{kg} / \mathrm{day})\end{array}$ & $\begin{array}{l}266=9.3 \\
P 4<0.05\end{array}$ & $\begin{array}{l}21 S=6.8 \\
P 4<0.05\end{array}$ & $\begin{array}{l}150 \pm 0.1 \\
P+<0.05\end{array}$ & $\begin{array}{l}7.3 \pm 0.1 \\
P+<0.05\end{array}$ \\
\hline
\end{tabular}

$\mathrm{SE}=$ standard et ror .

$P 1=$ test of significance between cirrhotic ascitic non-treated is non-cirrhotic control rats.

P2 = test of significance between cirrhotic ascitic rats treated with ramipril vs cirrhotic control.

$\mathbf{P} 3=$ test of significance between cirrhotic rats treated with valsartan vs cirrhotic control.

$\mathrm{P} 4=$ test of significance between cirrhotic rats treated with combination of ramipiril \& valsartan vs cirrhotic control rats.

Vol. 36, Nc. 3 \& 4 July., \& Oct, 2005 
Table (2): Effect of intragastric administration of ramipril and valsartan on plasma sodium, potassium, serum creatinine \& plasma renin activity (Mean $\pm \mathrm{SE}$ ).

\begin{tabular}{|c|c|c|c|c|}
\hline $\begin{array}{l}\text { Animal group } \\
\qquad N=6\end{array}$ & $\begin{array}{c}\text { Plasma } \\
\text { sodium } \\
(\mathrm{m} \mathrm{mol} / \mathrm{L}) \\
\end{array}$ & $\begin{array}{c}\begin{array}{c}\text { Plasma } \\
\text { pot:assium } \\
(\mathrm{m} \mathrm{mol} / \mathrm{L})\end{array} \\
\end{array}$ & $\begin{array}{l}\text { Serum } \\
\text { creatinine } \\
(\mathrm{mg} / \mathrm{dl})\end{array}$ & $\begin{array}{l}\text { PFit } \\
\text { ng/ml/hour }\end{array}$ \\
\hline Non-cirrinotic control & $143 \pm 0.5$ & $4.4 \pm 0.1$ & $0.9 \pm 0.01$ & $5.6 \pm 0.1$ \\
\hline Cirrhotic ascitic control & $\begin{array}{l}210 \pm 0.8 \\
P 1<0.001\end{array}$ & $\begin{array}{l}4.5 \pm 0.2 \\
\mathrm{Pl}>0.05\end{array}$ & $\begin{array}{l}3.6 \pm 0.08 \\
\mathrm{Pl}<0.001\end{array}$ & $\begin{array}{l}8.5 \pm 0.5 \\
\mathrm{Pl}<0.001\end{array}$ \\
\hline $\begin{array}{l}\text { Cirrhotic rats treated with ramipril } \\
(2.5 \mathrm{mg} / \mathrm{kg} / \text { day }) \text { for } 2 \text { week }\end{array}$ & $\begin{array}{l}180 \pm 0.9 \\
P 2<0.001\end{array}$ & $\begin{array}{l}5.3 \pm 0.1 \\
P_{2}<0.05\end{array}$ & $\begin{array}{l}2.5 \div 0.02 \\
P 2<C .05\end{array}$ & $\begin{array}{l}i 2.5 \pm 0.6 \\
P 2=0.01\end{array}$ \\
\hline $\begin{array}{l}\text { Cirrhotic rats treated with valsartan } \\
(20 \mathrm{mg} / \mathrm{kg} / \mathrm{day}) \text { for } 2 \text { week }\end{array}$ & $\begin{array}{l}175 \pm 0.8 \\
P 3<0.001\end{array}$ & $\begin{array}{l}5.1=0.2 \\
P 3<0.05\end{array}$ & $\begin{array}{l}21=0.01 \\
P 3<0.05\end{array}$ & $\begin{array}{l}12.1 \pm 0.3 \\
P_{3}<0.05\end{array}$ \\
\hline $\begin{array}{l}\text { Cirrhotic rats treated with combined } \\
\text { ramipril \& valsartan in previous } \\
\text { doses for } 2 \text { week ( } 2.5 \mathrm{mg} / \mathrm{kg} / \mathrm{day})\end{array}$ & $\begin{array}{l}160 \pm 0.7 \\
P 4<0.001\end{array}$ & $\begin{array}{l}5.3 \pm 0.3 \\
P 4<0.05\end{array}$ & $\begin{array}{l}1.8=0.03 \\
P 4<0.001\end{array}$ & $\begin{array}{l}12.8 \pm 0.4 \\
P 4<0.05\end{array}$ \\
\hline
\end{tabular}

$\mathrm{SE}=$ standard error

$\mathbf{P} \mathbf{1}=$ test of significance between cirrhotic ascitic non-treated vs non-cirrhotic control rats.

P2= test of significance between cirrhotic ascetic rats treated with ramipril vs cirrhotic control.

P3 $=$ test of significanice between cirrhotic rats treated with valsartan is cirrhotic control.

$\mathrm{P4}=$ test of significance between cirrhotic rats treated with combination of ramipiril \& valsartan vs cirrhotic control rats. 


\section{DISCUSSION}

In the present study cirrhosis induced by $\mathrm{CCl}_{4}$ was followed by a significant decrease in both urinary output \& urinary sodium excretion as well as significant increase in body weight and urinary potassium excretion. Furthermore cirrhotic rats showed increased serum creatinine \& PRA. These findings were in accord with Lopez-Novoa et al.(24), where they reported that rats with liver cirrhosis \& ascites were unable to excrete salt \& water promptly. However, the cause of the renal sodium \& water retention not completely elucidated, there are many theories about its pathogenesis $(25,26)$. It has been proposed that the major initiating factor is the peripheral arterial vasodilatation in the splanchenic circulation that activates baroreceptors mediated vasc uc striction, antinatriuretic \& antidiuretic response to counterregulate the underfilling of arterial circulation. This counter regulation in compensated cirrhosis is associated with an increased plasma volume but without ascites. However, when the cirrhosis progresses, decompensation occurs as defined by ascites formation.

Many liver diseases including various types of liver cirrhosis may be complicated by ascites. Conventional treatment of ascites with diuretics is frequently complicated by renal dysfunction \& electrolyte disturbances (27). A brisk diuresis results in contraction of extracellular fluid volume. Therefore, the use of angiotensin converting enzyme blocker may share in solving some of the above mentioned problems.

The present study reports that in a model of live: cirrnosis with ascites \& renal impairment, combination therapy with ramipril \& valsartan was more efficacious than either monotherapy in improving kidney function \& sodium \& water retention. Ramipril is as equally effective as valsartan at almeliorating the decline in renal function \& sodium \& water retention. A similarity in the renoprotective effects AT1 receptor blocker \& ACEI has been reported in a variety of studies that have been compared monotherapy vs combined therapy (28). The studies that have compared monotherapy vs combined AT receptor blocker \& ACEI have reported no additional benefit of combined therapy on renal structure \& function in the $5 / 6$ mass ablation models (29), cyclosporine induced interstitial fibrosis (30) and unineph- 
rectomized STZ diabetic spontaneously hypertensive rats (31).

In present study there are the attenuation of the decline in renal function in cirrhotic ascitic rats treated by combined valsartan \& ramipril. These findings are supported by studies of Willeinson et al. (24), they reported that combined valsartan \& perincopril treatment reduced albuminuria \& attenuated the decline in GFR (glomeular filtration rate) to similar extent as monotherapy in diabetic nephropathy.

The present study was performed in rats with liver cirrhosis \& ascites, which overexpresses various components of the RAS, including renin. These added reno protective effects afforded by combined RAS blockade in this model adds further support to the involvement of a tissue-based RAS. A number of studies suggested that an enhanced RAS may induce local injury $(29,31,32)$. Although the present study reveals elevation of PRA in either monotherapy or combined therapy, however RAS blockade improved renal function, indicating that local RAS blockades confers renoprotective effect.
Osteopontin (OPN) mediates progressive renal injury in various renal diseases by attracting macrophages, and its expression is regulated by the RAS(33). Up regulation of OPN expression may play a role in tubulointerstitial injury \& blockade of RAS by ramipril may confer renoprotective effect by decreasing OPN expression (33). It was suggested that valsartan has some renal protective effect in rats through down regulating tumour transforming growth factor beta-1 (TGF beta-1) expression \& reducing deposition of glomeurlar extracellular matrix ${ }^{(34)}$. Furthermore, Nagasawa et al . (34), reported that Angll has a direct effect on connective tissue cells \& their ability to produce extracellular matrix proteins. The direct effect of the reninangiotensin system on the activity of interstitial cells was further proven by molecular biology techniques showing an up regulation of transcription for collagen I \& II which was prevented by ACE inhibitor. (35).

\section{CONCLUSIONS}

Combination therapy of an $A T_{1}$ receptor blocker (valsartan) \& ACE1 (ramipril) appears to be approach for developing effective natriuresis \& decreased deterioration in renal

:VAANSOURA MEDICAL JOUF:A: 
function associated with liver cirrhosis and ascites.

The enhancing effects of ramipril \& valsartan combination on renal electrolyte \& v'olume excretion may reduce the need for diuretics \& thus attenuated the risk of their induced electrolyte disturbance. These findings provide a rationale for applying such combination regimens in the prevention of hepatorenal syndrome. However this phencmenon may not occur in humans \& therefore one must be cautious in extrapolating these findings in humans.

\section{REFERENCES}

1-Lee JK, Hsieh JF, Tsai SC, Hoyt \& $\mathrm{KaoCH}$ (2000) : Effect of single dose of $50 \mathrm{mg}$ captopril in patients with liver cirrhosis \& ascites. Hepatogastroenlerology; 47 (33): 767-70.

2- Arroyo v, Bosch J \& Mauri M (1979) : Renin, aldosterone \& renal haemodynamics in cirrhosis with ascites. Eur $\mathrm{J}$ clin Invest; 9:69-73.

3- Garcia-pagan JC, Bosch J \& Rodes J (1995) : the role of

Vol. 36, No. 3 \& 4 July., \& Oct, 2005 vasoactive mediators in portal hypertension. Semin gastrointest Dis; 6:140-7.

4-Nussberger-waeber B \& Brunner HR (1989) : Clinical pharmacology of ACE inhibitor. Cardiology; 76 (suppl2): 11 22.

5- Mitchell KD, Braam B \& Navar LG (1992) : Hypertensinogenic mechanisms mediated by renal actions of reninangiotensins system. Hypertension; 19 (suppl.1) 118-127.

6- Carretero OA, Miyazaki S \& Scicli AG (1981): Role of kinins in acute anti hypertensive activity of the converting enzyme inhibitor, captopril. Hypertension; 3: $18-22$.

7- Erd SE G(1990) : Angiotensin I converting enzyme \& the changes in our concepts through the years, Hypertension; 16:363-370.

8- Campbell DJ, Kladis A \& Duncan Am (1994): Efffects of 
converting enzyme inhibitors on angiotensin \& bradykinin peptides. Hypertension; 23:439-449.

9- Lui YH, Yang XP \& Sharov VG (1997) : Effect of angiotensin-converting enzyme inhibitors \& angiotensin II type 1 receptor antagonists in rats with heart failure. Role of kinins \& angiotensin II type-2 receptors. J clin Invest; 99 : 1929-1935.

10- Mooser V, Nussberger J, Juillerat (1990) : Reactive hyperreninemia is a major determinant of plasma angiotensin II during ACE inhibition, J Cardiovasc. Pharmacol, 15:276-282.

11-Chung-okuhl H, StollM \& Unger T. (1998) : Physiologicai \& pharmacological complications of AT1 versus AT2 receptor. Kidney int, 54 (suppl. 67) 595-599.

12- Vasmant $D$ \& Bender. $N$ (1989) : The renin angiotensin system \& ramipril, a new con- verting enzyme inhibitor. $J$ cardiovasc pharmcol; 14 (suppl.4): S46-52.

13- Thurmann PA (2000) : Valsartan: a novel angiotensin type-1 receptor antagcnist. Expert opin pharmacother; 1(2) 337-50.

14- Proctor \& Chatamara K (1982) : High yield micronodular cirrhosis in the rat. Gastroenterology; 83:1183-1190.

15- Jimenez W, Claria J, Arroyo V \& Rodes J (1992) : Carbon tetrachloride induced cirrhosis in rats: a useful tool for investigating the pathogenesis of ascites in chronic liver disease. J gastroenterol Hepatol; 7:90-97.

16- Levy M (1983) : Increased sympathetic activity in cirrhosis. N Eng. J Med; 308-1031.

17- Pierrey, Martinves, Mamiko 0 \& Pese G (1998) : Nitric oxide synethase (NOS) inhibition for one week improve renal sodium \& water excretion in cirrhosis rats with asMANSOURA MEDICAL JOURNAL 
cites. J clin Invest; 101:235242.

18- Sealay JE (1991) : Plasma renin activity \& prorenin assays. Clin Chem.; 37:1881-90.

19- Levy GB (1981) : Determination of sodium with ion-selective electrodes. Clinical Chemistry; 27:1435-1438.

20- Seeling HP \& Wust H (1969) : Determination of serum \& urine creatinine. Clinical Chemistry, 2nd editions pp:525.

21- Cachoferio V, Maeso R, Rodrigo E, Navarro J, Ruilope LM \& Lahera V (1995) : Nitric oxide \& prostaglandins in the prolonged effects of losartan \& ramipril in hypertension. Hypertension; 26:236-243.

22- Wilkinson-Berka JL, Gibbs NJ, Cooper ME, Skinner SL \& Kelly DJ (2001) : Renoprotective \& antihypertensive effects of combined valsar$\tan \&$ perindopril in progressive diabetic rephropathy in the transgenic (m Ren-2) 27 rat. Nephrology dialysis transplantation; 16: 13431349.

23- Pipkin FB (1984) : Statistical analysis of the obtained data by descriptive \& comparative analysis in "Medical statistics made ease" Charchill livingstone publications, London, Melbourne\& New York.

24- Lopez-Novoa J, Manuel A, Jose L \& Luis H (1977) : A micropuncture study of salt \& water retention in chronic experimental cirrhosis. Am J physiol; 232(4): F315-F318.

25-Ohnishi A, Ishizaki T, Murakani S \& Tanaka T (1990) : Intra patient comparison of acute hemodynamic, hormonal and natriuretic responses to captopril versus enalapril in liver cirrhosis. Clin pharmacol ther; 48(1):67-75.

26- Rodes J (1988) : Periphehal arterial vasodilation hypothesis: a proposal for the initiation of renal sodium \& water

Vol. 36, No. 3 \& 4 July., \& Oct, 2005 
retention in cirrhosis. Hepatology; 8:1151-1157.

27- Brater DC (1998) : Diuretic therapy. $\mathrm{N}$ Engl. J. of Medicine. 339:387-395.

28-Zoja C, Donadelli R \& Corna D (1997) : The reroprotective properties of angiotensin converting enzyme inhibitors in a chronic model of mem. branous nephropathy are solely due to the inhibition of angiotensin II: Evidence based on compartive studies with a receptor antagonist. Am J Kidney Dis. 29:254-264.

29- Ost M, Mackenzie HS, Troy JL, Rennke HG \& Brenner BM (1998) : Effects of combination therapy with enalapril \& Losartan on the rate of progression of renal injury in rats with $5 / 6$ renal mass ablation. Jam Soc Nephrol.; 9:224-230.

30- Burdmann EA, Takeshi FA \& Nastc C (1995) : Prevention of experimental cyclosporine-induced interstitial fibro- sis by losartan \& enalapril. Am J physiol; 269:F491. 499.

31-Kohzuki M, Yasujima M \& Kanazawa M (1995) : Antihypertensive \& renalprotective effects of losartan in streptozotocin diabetic rats. J Hypertens; 13:97103.

32-Kelly DJ, Skinner SL, Gilbert RE, Exo AJ, Cooper ME \& Wilkinson Berka J (2000) : Effects of endothelin or angiotensin receptor blockade on diabetes in transgenic (in Ren-2) 27 rats. Kidney Int. 57: $1882-1894$.

33- Lic, Yang CW, Park CE, Ahn HJ, Kim WY, Yoon $K H$, Such SH \& Lim SW (2003) : Long term treatment with ramipril attenuates renal osteopontin expression in diabetic rats. Kidney Int. 63 (2) 454-63.

34- Wen H \& Lins (1999) : Renoprotective effect of valsartan in diabetic rats. Zhonghua Neike Za zhi; 38(3)157-60.

MANSOURA MEDICAL JOURNAL 
68 STUDY OF THE RENAL RESPONSE TO RAMIPRIL OIC.

35-Nagasawa K, Zimmermann R,

Munkel B, Scholkens B

\& Schaper J (1995) :

Extracellular matrix deposi-

tion in hypertensive hearts, anti fibrotic offocts of ramipril. Eur Heart J; 16 (Suppl C): 33-7.

Vol. 36, No. 3 \& 4 July., \& Oct, 2005 


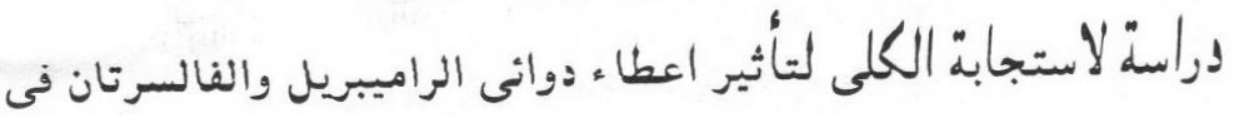

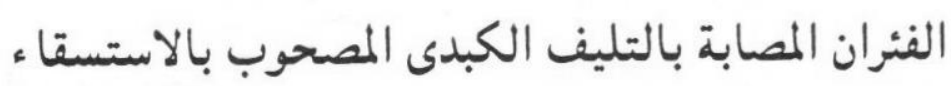

\author{
د.كـروان محمـد \\ تسم الفارماكولوجى - كلبة الطب - جامعة المنصورة - جمهورية مصر العربية
}

تمت دراسة اعطا ، كلا م دوائى الراميبريل (مثبط لانزيم النجبيوتنسين والفالسرتان (تانل لمستقبلات

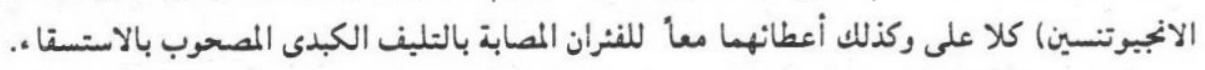

استخدام لاجراء هذا البحث عدد ـا (ثلاثون) فأرا أبيضاً منن الذكور، يتراوح وزن الواحد منهم مابين

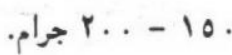

تم تقسيم الفثران الى خسة مجسوعات متساوية (؟ فيران فى كل مجسوعة) :ا - مجموعة ضابطة عادية عولجت بمحلول ملح عادى (9ر \%) وذلك عن طريق الفم لمدة أسبوعين.

r- مجموعة ضابطة مصابة بالتليف الكبدى المصحوب بالاستسقا ، عولجت بأيضا بحلول الملح عن طريق الفم لمدة أسبوعين.

r- مجسموعة مصابة بالتلبف وأعطبت دواء الرامببريل وبجرعة مرب مسجم/كجم يومباً لمدة أسبوعين

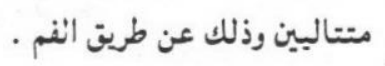

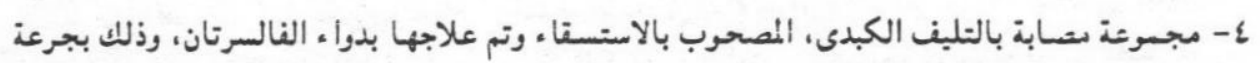

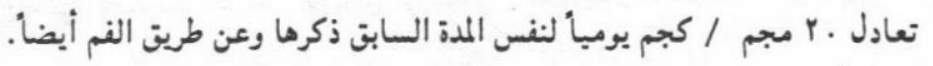

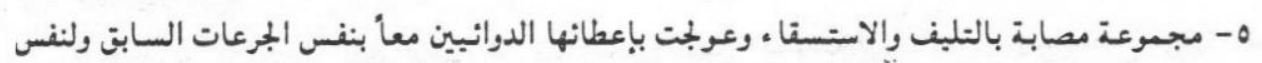
المدة عن طريق الفم أبضاً. 
وتم تقييم تأثير استخدام هذه الأدوية بواسطة المعايير الآتية :- متابعة تباس وزن الجسم يومباً . - تباس نسبة كل من الصوديوم والبوتاسبوم فى البول وكذلك فى البلازما وأيضاً تباس كمبة

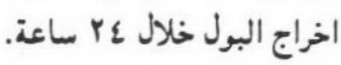
- تياس نشاط الرنين فى البلازما. - تباس نسبة الكرياتبنين فى المصل . ويمن تلخيص ننتائج هذا البحث كالتالى :-

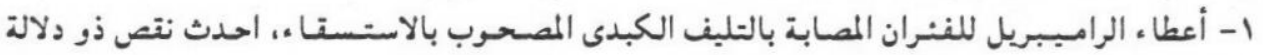

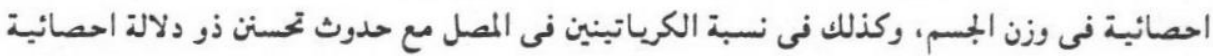

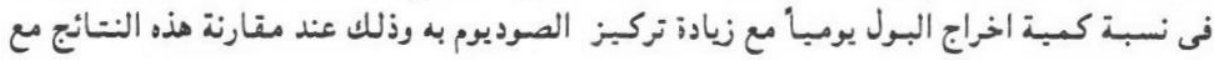

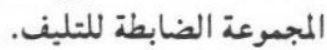

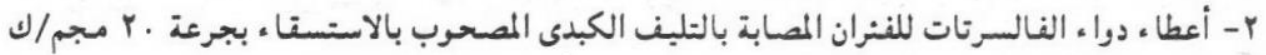

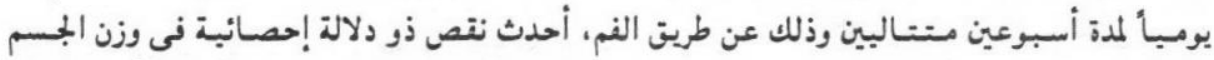

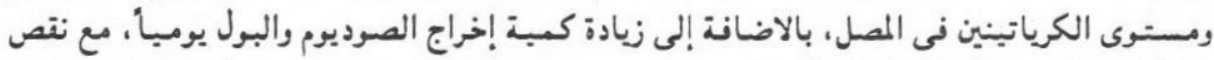

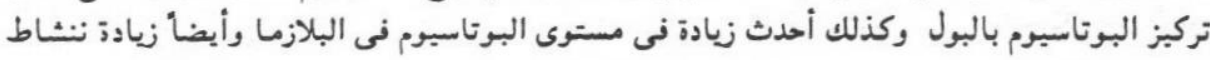
الرنين فى البلازما وذلك بالمقارنة مع المجموعة الضابطة للتليف.

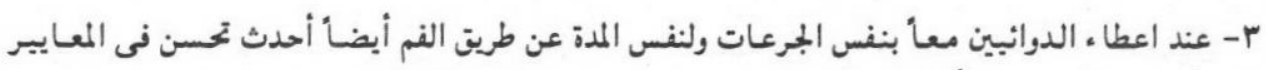

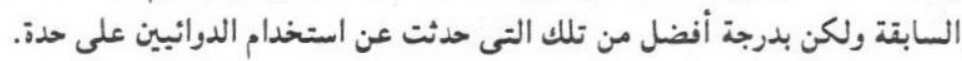

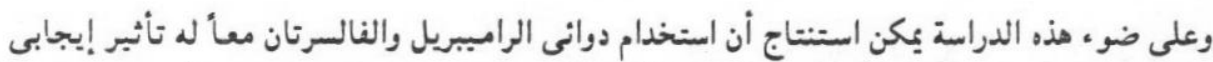

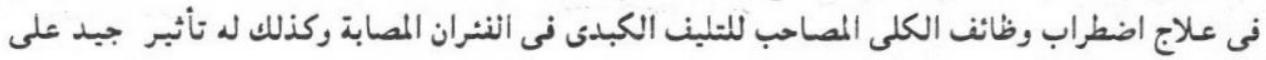
اخراج السوائل والأملاح.

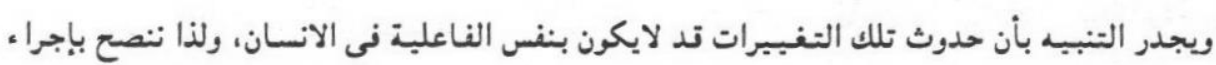

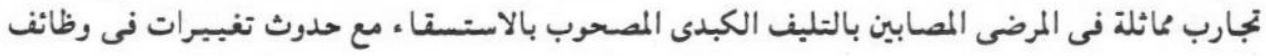

